„Bohemistyka” 2021, nr 3, ISSN 1642-9893

Karolína TÁBORSKÁ

DOI: $10.14746 /$ bo.2021.3.10

Univerzita Karlova

\section{ÚSPĚCH v české frazeologii}

Keywords: phraseology, idiom, cognitive linguistics, success

Klíčová slova: frazeologie, frazém, kognitivní lingvistika, úspěch

\section{Abstract}

This paper deals with the issue of the linguistic picture of the world of the SUCCESS concept. This is an initial and partial research focused on systemic data within the dissertation, which deals with the notion of SUCCESS in the linguistic picture of the world of Czech pupils. Its subject is cognitive linguistic analysis of phraseological material in order to get an initial idea about the conceptualization of said concept in the Czech language environment. Conceptual metaphors and image schemata associated with this concept are gradually revealed.

Př́ispěvek je věnován problematice jazykového obrazu světa konceptu ÚSPĚCH. Jde o prvotní, dílčí výzkum zaměřený na systémová data $\mathrm{v}$ rámci disertační práce, která se věnuje pojmu ÚSPĚCH v jazykovém obrazu světa českých žákủ. Předmětem je kognitivně-lingvistická analýza frazeologického materiálu s cílem udělat si počáteční představu o konceptualizaci tohoto pojmu v českém jazykovém prostředí. Postupně odhalujeme představová schémata a konceptuální metafory, které se s tímto pojmem pojí.

\section{1. Úvodem}

Úspěch je důležitou hodnotou v životě každého člověka, byt' ne nezbytnou a nepostradatelnou. S tímto pojmem se setkáváme už v dětství. Děti ve svých představách o budoucím životě často reflektují úspěchy vzdělávací, pracovní, sportovní i rodinné. Vnímání úspěšnosti se akcentuje zejména s nástupem do školy, kde i děti, které nemají sourozence, mají více př́ležitostí k vzájemnému srovnávání. Postupem času jedinec zjišt'uje, že za každým dílčím úspěchem v ja- kékoliv oblasti života stojí obvykle tvrdá práce a čas, který je potřeba jí věnovat.

Tento př́spěvek má za cíl být dílčí kognitivně-lingvistickou analýzou konceptu ÚSPĚCH ${ }^{1}$ v českém jazykovém obrazu světa. Teoreticky se opíráme o principy kognitivní lingvistiky, o jejíž zakotvenosti v české jazykovědě svědčí domácí monografie (Vaňková et al., 2005; Vaňková 2007; Vaňková, Št'astná et al. 2018)², sborníky z konferencí zaměřených na různá témata $\mathrm{z}$ kognitivní lingvistiky (Obraz světa v jazyce 2001; Obraz světa v jazyce II 2007; Télo, smysly, emoce $v$ jazyce / Tělo, smysly, emoce v literatuře 2012) a četné příspěvky v odborných periodicích (viz monotematické číslo časopisu Didaktické studie, 2014, roč. 6, č. 1, kde se témata kognitivně-lingvistická setkávají s tématy didaktickými).

V této koncepci je jazyk chápán jako součást poznávacích (kognitivních) schopností člověka, které mají zásadní podíl na tom, jak rozumíme světu kolem nás (Vaňková 2013, s. 5). Reprezentuje je především ,schopnost konceptualizovat, tj. uchopovat určité situace nebo fragmenty skutečnosti v podobě pojmů (konceptů) či pojmových (konceptuálních) struktur, které jsou ze své podstaty spjaty s jazykem. Tyto pojmy a pojmové struktury mohou mít podobu lexikálního významu, ale i významů gramatických kategorií či konstrukcí.“(Vaňková 2013, s. 5).

Kognitivní lingvistika tedy zkoumá význam z hlediska celého konceptuálního systému a jeho zakotvení v jazykovém obrazu světa ${ }^{3}$,

${ }^{1}$ Pro jednoznačnost a snadnější orientaci v textu používáme zažitou diferenci formu ÚSPĚCH použiváme, mluvíme-li o konceptu, formou úspěch označujeme lexém nebo pojmenování.

${ }^{2} \mathrm{Z}$ hlediska formy stojí na pomezí monografie a slovníku také práce, které se věnují jednotlivým klíčovým slovům ve slovanských jazycích. Tyto práce vznikají $\mathrm{v}$ rámci projektu EUROJOS, $\mathrm{v}$ první fázi vznikly monografie věnované pěti konceptům. Pro češtinu byly zpracovány koncepty DOMOV (Vaňková 2015), SVOBODA (Vaňková, Vodrážková 2019) a PRÁCE (Janovec, Wildová 2016).

${ }^{3}$ K termínu viz např. Vaňková 1999, s. 283-295; Vaňková et al. 2005, s. 46-59; Vaňková 2007, s. 58-64. 
nikoliv pouze vztahy mezi lexikálními (i jinými) jednotkami jako je tomu v strukturalisticky orientovaných lingvistických směrech. Při analýze významu se pozornost věnuje nejen složce denotativní, ale i konotacím a asociacím, které jsou $\mathrm{v}$ daném momentu s určitým výrazem spjaté v pojmovém systému rodilých mluvčích. ${ }^{4}$

Myšlení a jazyk jsou z hlediska kognitivní lingvistiky natolik vzájemně propojené, že specifickým studiem jazyka je možné se dobrat zásadních poznatků o fungování lidské mysli v kontextu doby i daného jazykového společenství. Vaňková připomíná ,,pojetí jazyka jako základu národní svébytnosti a kultury. V jazyce je totiž obsažena interpretace skutečnosti (nikoli její zrcadlový »odraz«), souhrn-nebo spíše struktura - soudů o světě, které jsou vlastní určitému lidskému společenství““ (Vaňková 2007, s. 58).

\section{Systémová data}

Představová analýza je prvotní sondou do studia konceptu ÚSPĚCH $\mathrm{v}$ českém jazyce, a to na základě systémových dat, nebot' se zaměřuje primárně na frazeologický fond českého jazyka, jak je shromážděný v českých frazeologických slovnících a souborech frazémů a parémií. $\mathrm{K}$ deskripci sémantického spektra pochopitelně využíváme i informace získané z jiných druhů slovníků, výkladových, synonymických a etymologických. Nejde tedy o komplexní a úplnou deskripci pojmu, spiśs o určitý výsek jazykového obrazu světa, na nějž je pozornost v této studii zaměřena ${ }^{5}$.

Jazykový materiál jsme získali ze základních př́ruček české frazeologie starší i současné. Jedná se o práce Čelakovského (2000, poprvé publikováno v roce 1852, dále Čel), Zaorálka (1996, dále Zao),

${ }^{4}$ Rozdíl mezi konotací a asociací je chápán různě, my vycházíme z kognitivně-lingvistického chápání, podle něhož je konotace ukotvena $v$ jazykovém systému a představuje podstatnou, kulturně sdílenou součást významu lexému, zatímco asociace jsou spíše subjektivní a nemusejí být kulturně sdílené.

${ }^{5} \mathrm{~V}$ další fázi výzkumu budeme pracovat s daty textovými (např. korpusovými) a empirickými, která získáme na základě dotazníkového šetření.
Bittnerové a Schindlera (2003, dále Bitt) a Čermáka et al. (Slovník české frazeologie a idiomatiky 1-5, dále SČFI). Dále jsme pracovali se slovníky výkladovými (Slovník spisovné češtiny 1994, dále SSČ; Slovník spisovného jazyka českého 1966, dále SSJČ; Přiručni slovnik jazyka českého 1935-1957, dále PSJČ) a synonymickými (Haller, Šmilauer 1977; Klégr 2007; Pala, Všianský 2000). Dílčím zdrojem poznání při analýze pojmu byly rovněž české slovníky etymologické (Machek 1968; Rejzek 2012).

\section{Etymologie, popis významu, synonymie}

České etymologické slovníky uvádějí, že praslovanské *uspěch (rusky uspéch, chorvatsky ùspjeh, slovinsky ùspeh, staroslověnsky uspěchъ) pochází z verba *uspěti s významem uspět, prospět. Rejzek (2012, s. 624) i Machek (1968, s. 570) se shodují, že slovo úspěch bylo do češtiny pravděpodobně převzato z ruštiny. Lexém významově souvisí s praslovanským slovesem *spěti s původním významem ,prospívat, postupovat $\mathrm{k}$ cíli‘, který pochází z indoevropského *spē s významem ,prospívat, dobře růst ${ }^{\circ}$

SSČ (1994, s. 474) i SSJČ (1966, s. 1027) shodně popisují význam lexému úspěch jako ,kladný výsledek nějaké činnosti, zdar', tedy jako lexém monosémní. PSJČ (1935-1957, s. 621) kromě významu primárního uvádí další dva významy:

1. pro s p ě c h (Pana Viktora jsem prohlídnul. Jeho odstoupeni k úspěchu mému-jak pravil-neprijijimám.). Tento význam PSJČ uvádí jako řídký.

2. u s pě c há ní, ú p a d (Jeník tančil jako do úspěchu.). Tento význam byl již v době práce na PSJČ vyhodnocen jako málo užívaný.

Koncept ÚSPĚCH je v českém jazyce realizován několika lexémy. Za neutrální jednotku stojící v centru slovní zásoby považujeme lexém úspěch. Dále jej je možné vyjádřit variantním lexémem úspěšnost, knižním výrazem zdar nebo přejatým lexémem sukces, který SSČ považuje za zastaralý, a tudíž málo frekventovaný. SSČ uvádí $\mathrm{v}$ rámci hesla úspěch i expresivní deminutivum úspěšsek. Tezaurus 
jazyka českého (Klégr 2007, s. 382) uvádí jako slova synonymní nebo blízká lexémy úspěšnost, ohlas, skvělý výkon, pokrok, štěstí, triumf. Ve Slovníku věcném a synonymickém (Haller, Šmilauer 1977, s. 627) najdeme jako významově blízké lexémy úspěšnost, zdar, povedenost, prospěch, znamenáni, výhra, vitězství, triumf, vavřin, palma, štěstí, prosperita, růst, vzestup, zdařeni, výsledek, prospěch, vznik, vzkvět, sukces.

Korpusový materiál nám ukazuje, že úspěch je lexém v češtině velmi frekventovaný ${ }^{6}$, užívaný jak v běžné komunikaci, tak v textech publicistických, v odborných textech různých oborů i v beletrii. Podle údajů ve Frekvenčním slovníku mluvené češtiny (Čermák et al. 2007, s. 509) patří adjektivum úspěšný a jeho nespisovná varianta úspěšnej mezi sto nejfrekventovanějších českých adjektiv.

\section{4. ÚSPĚCH v české frazeologii}

Frazémy představují důležitý zdroj pro posouzení axiologičnosti konceptu, nebot' jde o ustálené, kulturně hluboce zakořeněné vyjadřovací jednotky, které reflektují myšlenkové procesy daného lidského společenství, protože fixují jeho obraznost, emoce a postojovost, a tím pádem i vnímání světa.

Na základě analýzy frazeologického materiálu bylo možné vymezit několik schémat podle toho, jakým způsobem je v nich pojem metaforizován. Pracujeme zde $\mathrm{s}$ některými $\mathrm{z}$ představových schémat, která v publikaci Body in the Mind, ale později i jinde, představil Johnson (Vaňková 2013, s. 43). Ta tvoří základ lidského pojmového systému, na jejichž základě jsou formovány konceptuální metafory, které jsou chápány jako základní prostředek konceptualizace v jazyce.

Pojetí metafory v kognitivní lingvistice se odlišuje od jejího tradičního vymezení jako básnického prostředku, tedy jazyka zpravidla psaného a neobvyklého. Lakoff a Johnson chápou metaforu nejen jako

\footnotetext{
${ }^{6}$ Pro lexém úspěch se v korpusu SYN verze 8 z roku 2019 jedná o 1117855 výskytů.
}

prostředek jazykový, ale (a to zejména) jako prostředek lidského myšlení a chování, který prostupuje celý náš každodenní život (Lakoff, Johnson 2002, s. 15). Lakoff a Johnson nově také zavádějí tř̌i typy metafor, a to metaforu orientační, metaforu strukturní a metaforu ontologickou.

Metafora strukturní je založena na principu přenášení významu mezi oblastí zdrojovou a oblastí cílovou. Zdrojové oblasti jsou obvykle vázány na smyslovou (konkrétní) zkušenost člověka, zatímco cílové oblasti mají povahu abstraktní. Jeden pojem tedy metaforizujeme na základě pojmu druhého.

Zdrojové oblasti orientačních metafor jsou obvykle různé druhy prostorově orientovaných opozic (např. NAHOŘE - DOLE, VPŘEDU VZADU, CENTRUM - PERIFERIE), které vyjadřují význam pojmu jeho orientací v prostoru ve vztahu k lidskému tělu. Tyto metaforické systémy jsou velmi často kulturně podmíněny - co se nachází nahoře, směřuje vzhưru, je chápáno jako pozitivní a naopak co se nachází dole, nebo tam směřuje, chápeme negativně.

Metafory ontologické reflektují naše zkušenosti s konkréty a zkušenost s jejich materiální podstatou aplikují na abstrakta. O abstraktních pojmech se tedy $\mathrm{v}$ jazyce vyjadřujeme jako o konkrétech. K ontologickým metaforám řadí Lakoff a Johnson také personifikaci - abstraktní pojem má povahu živé bytosti (Vaňková 2007, s. 69-71).

V pracích Čermáka a Bittnerové, Schindlera nalezneme následující frazémy, které komponent úspěch obsahují - SČFI: tajemstvi úspěchu; čestný úspěch; laciný úspěch; nesporný úspěch; stř́ldavé úspěchy; těžce/tvrdě vydobytý/vybojovaný úspěch; draze zaplacený úspěch; být korunován úspěchem; úspěšně něco završit; dělat něco/ pokoušet se o něco se stř́lavým úspěchem; setkat se súspěchem; sklizet úspěchy; Bitt: Trpělivost je klíčem k úspěchu.; Je lepši umilovat se $k$ smrti, než v domově di̊chodců vzpominat na pracovní úspěchy. U Čelakovského a Zaorálka frazémy s tímto komponentem nenajdeme vůbec. Dále vycházíme z cílových oblastí konceptu, analyzujeme tedy struktury ,ÚSPĚCH JE XY“. 


\section{1 ÚSPĚCH JE NAHOŘE}

Na prvním místě uvádíme metaforu založenou na konceptuálním schématu protipólů NAHOŘE - DOLE. Zdravé lidské tělo je za standardních podmínek vzpřímené, a proto je tento stav spojován s hodnotami veskrze kladnými, jako je úspěch, štěstí, zdraví atd. ÚSPĚCH se tedy v našem pojmovém systému nachází NAHOŘE. Dokládají to následující frazeologická vyjádření: být korunován (úspěchem); (úspěšně) něco završit; na výsluní slávy/přizně/štěstí; být na výši situaceldne; mit nad někým (na)vrch; úspěšně něco završit; dostat se nahoru; dostat se vysoko; Pozdrav, když jdeš nahoru, aby tě lidi zdravili, až půjdeš dolü.; Č́m výše kdo sedí, tím hlouběji padá.; Dostal se na koně.; Už je zas na koni.; Jde mu vzhưru.

\section{2 ÚSPĚCH JE CESTA}

Na druhém místě uved'me konceptuální schéma CESTA, nebot' je v našem materiálu zastoupeno velmi hojně. V prvé řadě je koncept ÚSPĚCH v české slovní zásobě metaforizován jako cíl cesty (dobrý/ št’astný/zdárný konec; dotáhnout/dovést to někam/daleko; je to na dobré cestě; vést $k$ cíli; dobře pochodit; projít u zkoušky). Proces dosahování úspěchu pak představuje cestu samu (je to na dobré cestě; vést $k$ cíli).

Na cestě se jedinec může setkat s různými překážkami a nepř́ijemnostmi, které je potřeba překonat. Pokud se mu to podaří, může říct, že to/něco má za sebou. Úspěch rovněž bývá metaforizován jako bod na cestě, jako někdo/něco, s kým/čím se na cestě setkáváme (setkat se/ setkávat se súspěchem). Pokud na cestě za úspěchem zvolíme chybnou metodu, je cesta neúspěšná (takhle daleko nedojde).

Toto schéma stojí rovněž na pozadí př́sloví a pořekadel jako: $\mathrm{Ne}$ vede to $k$ žádnému cíli.; Tudy cesta nevede.

\section{3 ÚSPĚCH JE NÁMAHA, ÚSILÍ, BOJ}

Úspěch má v lidském společenství svoji nezpochybnitelnou hodnotu a jeho dosažení vyžaduje určitou míru (často fyzické) námahy a úsilí (lámání rekordi̊; udělat díru do světa; prorazit smůlu; dotáhnout to někam/daleko; táhne na dobrém konci; tvrdě vydobytý/vybojovaný úspěch; rozlousknout tvrdý ořišsek), které je někdy potřeba opakovat (do třetice všeho dobrého), protože úspěch je nestálý, vrtkavý, nejistý (se stř́idavým úspěchem; stř́davé úspěchy; dělat něco se stř́davým úspěchem). Úspěch, kterého člověk dosáhne bez úsilí je chápán jako nezasloužený (spadlo mu to do klina).

\section{4 ÚSPĚCH JE PLOD, ÚRODA}

V dalším bodě zmiňme metafory, které ÚSPĚCH konceptualizují jako rostlinu, jejíž plody můžeme sklízet poté, co jsme o ni nějaký čas pečovali. Opět je zde implicitně akcentována námaha, již musíme pro dosažení kýženého výsledku vynaložit. Pokud o rostlinu nepečujeme, nemůžeme sklízet její plody (požehnané ovoce; ovoce (něčí práce); palma vítězství; sklizet úspěchy; sklidit potlesk; kvete mu tam pšenice; svět mu kvete; obili mu roste na zádech; žito mu na zádech roste; roste mu to pod rukou; práce mu kvete pod rukou; dohrabala se zrna; semlelo se mu na hody).

\section{5 ÚSPĚCH JE CENNOST}

ÚSPĚCH je často metaforizován také jako cenný předmět, za který je potřeba zaplatit (draze zaplacený úspěch; Za všechno se v životě platí.). Pokud člověk nevynaloží dostatečné úsilí na jeho získání, je takový úspěch ve frazémech metaforizován jako bezcenný, levný (laciný úspěch).

\section{6 ÚSPĚCH JE UVNITŘ}

Dalším bodem je metafora založená na lakoffovsko-johnsnovském představovém schématu NÁDOBA, neboli UVNITŘ - VENKU. Úspěch je prostřednictvím tohoto schématu metaforizován jako obsah nádoby (představme si například trezor ukrývající poklad), za jejíž hranice se člověk musí dostat. Toho může dosáhnout opět bud' prostřednictvím 
námahy a úsilí (udělat díru do světa; prorazit smůlu), nebo prostřednictvím „klíče“, kterým může být např́klad určitá vlastnost nebo dovednost (Trpělivost je klíčem $k$ úspěchu).

\section{7 ÚSPĚCH JE (HAZARDNÍ) HRA}

$\mathrm{V}$ tomto schématu dochází $\mathrm{k}$ úzkému sepjetí pojmů ÚSPĚCH a ŠTĚSTí, nebot' $\mathrm{v}$ těchto metaforách již není akcentována námaha, jíž je pro dosažení úspěchu potřeba. Přesto však tento profil zařazujeme, jako další možnost, jak tento pojem chápat (dobrý tah; trefa do černého; hlavní trefa; výhra z loterie; první vyhrání; vsadit na správnou kartu; deljde/padá mu karta; jeho/má hra dobře stojï; dobře mu/mi kostka padá; vyhrál velikýlos; Kdoví, jak kostka padne.; Padlo mi tak, jak jsem žádal.).

\section{Závěrem}

Cílem tohoto příspěvku byla dílčí kognitivně-lingvistická analýza pojmu ÚSPĚCH nahlédnutá skrze jazyková data se zaměřením na frazeologii. Pojem ÚSPĚCH se uplatňuje v různých konceptualizacích spojených s pojmovými schématy NAHOŘE - DOLE, dále se schématem CESTA a schématem NÁDOBA. ÚSPĚCH je rovněž konceptualizován jako CENNOST, BOJ, PLODINA a HRA. Ćástečně se tak potvrdily počáteční předpoklady týkající se konotací daného konceptu ve frazeologii, a to, že akcentována je zejména pozitivní dimenze úspěchu. K řešení zůstává otázka aktuálnosti některých předložených frazémů. Domníváme se, že řada z nich (zejména pokud se jedná o materiál čerpaný ze starších slovníků) již není současným českým mluvčím známá. Dalším krokem ve výzkumu, bude rozširritit zkoumaný materiál o aktuální korpusová a textová data, aby bylo možné posoudit fungování stereotypu v současné češtině. Další otázkou, na kterou by bylo možné se z hlediska jazykového obrazu světa češtiny zaměřit, je vztah konceptů ÚSPĚCH a ŠTĚSTí, které jsou si velmi blízké a v některých metaforických vyjádřeních (viz podkapitolu 4.7 ÚSPĚCH JE (HAZARDNÍ) HRA) je obtížné rozhodnout, kdy se jedná o ten který pojem.

\section{Literatura}

B it t ne rová D., S c hindle r F., 2003, Česká př́sloví. Soudobý stav konce 20. století. Praha: Karolinum.

Č e la kovs ký F. L., 2000, Mudrosloví národu slovanského v prrislovích. Praha: Lika klub.

Č e r m á k F. et al., 2007, Frekvenční slovník mluvené češtiny. Praha: Karolinum.

Č e rmák F. et al., 2009, Slovník české frazeologie a idiomatiky 1. Přirovnání. Praha: Leda.

Č e r mák F. et al., 2009, Slovník české frazeologie a idiomatiky 2. Výrazy neslovesné. Praha: Leda.

Č e r m á k F. et al., 2009, Slovník české frazeologie a idiomatiky 3. Výrazy slovesné Praha: Leda.

Č e rmá k F. et al., 2009, Slovník české frazeologie a idiomatiky 4. Výrazy větné Praha: Leda.

Č e r m á k F. et al., 2016, Slovník české frazeologie a idiomatiky 5. Onomaziologický slovnik. Praha: Leda.

Filipe c J. et al., 1994, Slovník spisovné češtiny pro školu a veřejnost. Praha: Academia.

H a lle r J., Š mila u e r V. (ed.), 1977, Český slovník věcný a synonymický 3. Praha: SPN.

H avráne k B. et al. (ed.), 1966, Slovnik spisovného jazyka českého III (R-U). Praha: Academia.

J a n o v e c L., Wildová Z., 2016, PRÁCE v českém jazyce a jazykovém obrazu světa rodilých mluvčích. In Leksykon aksjologiczny Stowian i ich sąsiadów. Tom 3 - PRACA. Lublin: Wydawnictwo Uniwersytetu Marii Curie-Sklodowskiej, S. $129-156$.

K lé g r A., 2007, Tezaurus jazyka českého: slovník českých slov a frází souznačných, blizkých a príbuzných. Praha: Nakladatelství Lidové noviny.

Křen M., Cvrček V., Čapka T., Čermáková A., Hnátková M., Chlumská L., Jelínek T., Kovaříková D., Petkevič V., Procházka P., Skoumalová H., Škrabal M., Truneček P., Vondřičk a P., Z a sin a A., 2019, Korpus SYN verze $8 z$ 12. 12. 2019. Ústav českého národního korpusu FF UK, Praha. Online: https://www. korpus.cz.

L a k off G., J o h n s o n M., 2002, Metafory, kterými žijeme. Brno: Host.

M a c h e k V., 1968, Etymologickýslovník jazyka českého. 2. vyd. Praha: Academia.

P a c o v s ká J., 2014, Kognitivní přístup k didaktice mateřského jazyka - inspirace ze Slovenska. In: Didaktické studie, roč. 6, č. 1, s. 171-178. 
P a la K., V ši a n s ký J., 2000, Slovník českých synonym. Praha: Nakladatelství Lidové noviny.

Př́ruční slovník jazyka českého (1935-1957). Praha: Státní pedagogické nakladatelství.

R e j z e k J., 2012, Český etymologický slovnik. Vyd. 1. Voznice: Leda.

Šl édrová J. (ed.), 2007, Obraz světa v jazyce II. Praha: Filozofická fakulta, Univerzita Karlova v Praze.

V a ň k o v á I., 1999, Člověk a jazykový obraz (přirozeného) světa. „Slovo a slovesnost" 60 , č. 4, s. $283-292$.

V a ň k o vá I., 2007, Nádoba plná řeči. Člověk, reč a přirozený svět. Praha: Nakladatelství Karolinum.

V a ň k o vá I., 2013, Základy kognitivní lingvistiky. Praha: Univerzita Karlova, Filozofická fakulta, Ústav českého jazyka a teorie komunikace. Online: https://sites.ff.cuni.cz/ucjtk/wp-content/uploads/sites/57/2015/11/Zaklady_ kognitivni_lingvistiky.pdf

V aňková I., 2015, Český pojem DOMOV ve světle jazykových, empirických a textových dat. In: Bartmiński J., Bielińska-Gardziel I., Żywicka B. (eds.): Leksykon aksjologiczny Stowian $i$ ich sqsiadów. Tom 1 - DOM. Lublin: Wydawnictwo Uniwersytetu M. Curie-Skłodowskiej, 123-148.

V a ň k o vá I. (ed.), 2001, Obraz světa v jazyce. Praha: Filozofická fakulta, Univerzita Karlova v Praze.

V a ň k o vá I. et al., 2005, Co na srdci to na jazyku. Kapitoly z kognitivní lingvistiky. Praha: Karolinum.

Vaňková I., Čurdová V., 2014, Čelem k teorii pojmových profilů. Nové možnosti výkladu somatismů. In: Didaktické studie, roč. 6., č. 1, s. 66-78.

V aňková I., Št'as tná L. et al. (eds.), 2018, Horizonty kognitivně-kulturní lingvistiky II. Metafory, stereotypy a kulturní rozrůznénost jazyki̊ jako obrazů světa. Praha: Filozofická fakulta, Univerzita Karlova.

V a ň k o vá I., V i tk o v s k a y a V., 2014, Hlava: profily, subprofily, konceptuální schémata. Český somatismus v částečném porovnání s ruštinou. In: Didaktické studie, roč. 6, č. 1, s. 79-88.

V a ň k o vá I., V o d ráž k o vá V., 2019, SVOBODA v českém jazykovém obrazu světa. In: Abramowicz M., Bartmiński J. (eds.): Leksykon aksjologiczny Stowian i ich sasiadów,. Tom 4 - WOLNOŚĆ. Lublin: Wydawnictwo Uniwersytetu M. Curie-Skłodowskiej, s. 245-304.

V a ň k ová I., W i end 1 J., 2012, Tělo, smysly, emoce v jazyce / Tělo, smysly, emoce v literatuře. Praha: Univerzita Karlova, Filozofická fakulta, Ústav českého jazyka a teorie komunikace.

Z a o rále k J. 1996, Lidová rčení. Praha: Aurora. 